\title{
Strategi Pemerintah Nagari Ulakan dalam Mencegah Meluasnya Penyakit Masyarakat
}

\author{
Fajri Ferdiansyah, Maria Montessori \\ Program Studi Pendidikan Pancasila dan Kewarganegaraan \\ Universitas Negeri Padang \\ E-mail: fajriferdiansyah23@gmail.com
}

\section{ABSTRAK}

Penyakit masyarakat merupakan sebuah fenomena sosial yang ada di tengah-tengah kehidupan masyarakat. Di Nagari Ulakan, perilaku penyakit masyarakat yang terjadi sudah sangat meresahkan. Oleh karena itu pemerintah nagari Ulakan mengeluarkan suatu strategi untuk mencegah meluasnya penyakit masyarakat yang didasari oleh Peraturan Daerah Kabupaten Padang Pariaman Nomor 2 Tahun 2004 Tentang Pencegahan, Penindakan dan Pemberantasan Maksiat. Tujuan penelitian ini adalah untuk mengetahui dan mendeskripsikan mengenai strategi yang dilakukan pemerintah Nagari Ulakan dalam mencegah meluasnya penyakit masyarakat. Penelitian ini bertujuan untuk mendeskripikan fenomena penyakit masyarakat di Nagari Ulakan dan strategi Pemerintah setempat dalam mencegahnya. Jenis penelitian yang digunakan adalah kualitatif dengan metode deskriptif analitis. Penentuan informan menggunakan teknik purposive sampling. Penelitian ini menggunakan data primer dan data skunder yang diperoleh melalui observasi, wawancara dan studi dokumentasi. Hasil penelitian menunjukan bahwa fenomena penyakit masyarakat di Nagari Ulakan yang marak terjadi sudah sangat meresahkan masyarakat, umumnya prilaku tersebut dilakukan oleh generasi-generasi muda Nagari Ulakan. Adapun bentuk penyakit masyarakat yang terjadi diantaranya perjudian, narkotika dan miras. Strategi Pemerintah Nagari Ulakan dalam mencegah meluasnya penyakit masyarakat. Dalam mencegah meluasnya penyakit masyarakat ini, strategi yang dilakukan masyarakat Nagari Ulakan dilakukan secara Preventif yaitu dengan melakukan sosialisasi hukum, melakukan pendekatan secara keagamaan, mengaktifkan kegiatan olahraga serta karang taruna.

Kata Kunci: penyakit masyarakat, Peraturan Daerah Kabupaten Padang Pariaman, Nagari Ulakan

\section{ABSTRACT}

Penyakit Masyarakat is a social phenomenon in lives. In Nagari Ulakan the disease behavior of the people that had happened was very unsettling. For this reason, Nagari Ulakan government issued a strategy to prevent the spread of penyakit masyarakat based on the Padang Pariaman District Regulation No.2 of 2004 concerning Prevention, Enforcement and Eradication of the Immortal. The purpose of this study is to find out and described the strategies adopted by the Nagari Ulakan government in preventing the spread of this behaviour. This study aims to describe the phenomenon of community diseases in Nagari 
Ulakan and the strategies of the local government in preventing them. This research qualitative with descriptive analytical methods. This research using primary and secondary data obtained through observation, interviews and documentation studies. The results of the study showed that the phenomenon of Penyakit Masyarakat in Nagari Ulakan. This criminal that is rife in Nagari Ulakan is very disturbing for the community, generally the behavior is carried out by the younger generations of Nagari Ulakan. The forms of this behaviour occur include gambling, narcotics and alcohol. Nagari Ulakan Government Strategy in preventing the spread of this crime. In preventing the spread of this criminal, the strategy undertaken by the Nagari Ulakan community was carried out in a preventive manner by carried out legal socialization, approaching religiously, activating sports activities and youth organizations.

Keywords : penyakit masyarakat, Padang Pariaman District Regulation, Ulakan regency

\section{PENDAHULUAN}

Sebagai upaya mencegah dan memberantas berkembangnya gejala penyakit masyarakat, Pemerintah Kabupaten Padang Pariaman membentuk Peraturan Daerah Nomor 2 Tahun 2004 tentang Pencegahan, Penindakan dan Pemberantasan Maksiat. Dalam perda tersebut, yang termasuk perbuatan maksiat yang menjadi penyakit masyarakat antara lain segala bentuk perzinaan dan tindakan mengarah perzinaan, perjudian, minuman keras, penyalahgunaan narkotika serta obatobatan terlarang dan segala bentuk penyiaran tayangan porno dan pornografi. Selain itu, Perda Nomor 2/2004 tersebut juga mengamanatkan kepada masyarakat agar berperan serta dalam mencegah dan memberantas perbuatan-perbuatan maksiat.

Meski Perda Nomor 2/ 2004 telah diberlakukan selama lebih dari lima belas tahun, jumlah perbuatan yang termasuk penyakit masyarakat di Kabupaten Padang Pariaman belum sirna sepenuhnya. Sebelumnya terdapat 72 kasus penyakit masyarakat di tahun 2017, dan terus bertambah menjadi 76 kasus di tahun 2018 (Polres Padang Pariaman, 2018). Hal ini menunjukan terjadinya peningkatan kasus penyakit masyarakat di Padang Pariaman setiap tahun seperti data berikut:

Tabel 1

Jumlah kasus penyakit masyarakat di Kabupaten Padang Pariaman tahun 20172018

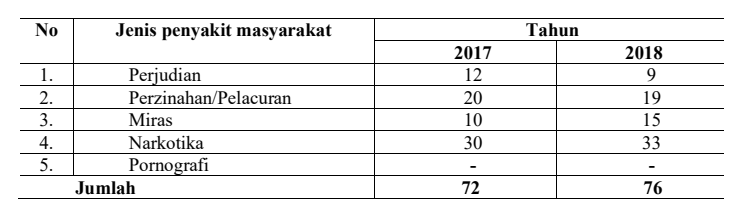

Sumber: Kepolisian Resor Padang Pariaman, 2018

Dari tabel 1 tersebut dapat dilihat perkembangan kasus penyakit masyarakat di Kabupaten Padang Pariaman. Kasus-kasus tersebut terjadi hampir di seluruh daerah yang berada dalam wilayah Kabupaten Padang Pariaman, salah satunya Nagari Ulakan. Nagari Ulakan sendiri dikenal sebagai nagari yang kental dengan nuansa keagamaan dan adatnya, mengingat bahwa nagari ini secara historis merupakan basis awal 
penyebaran agama Islam di masa lalu. Mengingat masih banyaknya kasus penyakit masyarakat di Nagari Ulakan, yakni 10 kasus per 2018, dalam kaitannya dengan implementasi Perda No. 2/2014, maka sangat penting untuk mengetahui strategi Pemerintah Nagari Ulakan dalam mencegah meluasnya penyakit sosial di nagari tersebut.

Hingga saat ini terdapat beberapa penelitian terdahulu yang relevan dengan tema penelitian ini. Seperti penelitian Afrizal \& Adynata (2014) dalam penelitiannya tentang Penyakit Masyarakat di Kecamatan Bangkinang Kabupaten Kampar yang lebih membahas tentang adanya faktor-faktor penyebab utama dari penyakit masyarakat antara lain kurangnya pengetahuan dan pengalaman di bidang agama, kurangnya perhatian dari orang tua, ekonomi dan pendidikan masyarakat yang tergolong rendah. Berbeda dengan penelitian ini yang membahas mengenai fenomena penyakit masyarakat yang meliputi bentukbentuk penyakit masyarakat dan faktor penyebab yang terjadi serta strategi yang dilakukan pemerintah Nagari Ulakan dalam mencegah meluasnya penyakit masyarakat.

Kemudian penelitian Ardila (2016), yang membahas upaya-upaya yang dilakukan oleh pihak kepolisian dalam menangani prostitusi sebagai penyakit masyarakat baik secara preventif maupun represif. Dalam penelitian ini lebih memfokuskan kepada upaya pihak kepolisian dalam penanggulangan kasus prostitusi yang terjadi. Berbeda dengan penelitian ini yang lebih membahas kepada upaya pemerintah nagari yang merupakan pihak yang berada langsung ditengahtengah kehidupan masyarakat.

Senada dengan penelitian Simanjuntak (2013) tentang upaya Polri dalam menanggulangi tindak pidana perjudian toto gelap (togel), yang meliputi upaya preventif, represif dan pelatihan keterampilan bagi masyarakat. Hasil penelitian ini menunjukkan bahwa penegakan hukum dalam rangka menanggulangi perjudian togel di kalangan masyarakat meliputi beberapa faktor seperti faktor hukum, penegak hukum, sarana atau fasilitas yang mendukung penegakan hukum, masyarakat serta kebudayaan. Hambatan yang dihadapi dalam menanggulangi perjudian togel dikalangan masyarakat dihadapkan pada usia muda dan ekonomi masyarakat yang rendah. Sehingga pihak aparat penegak hukum berbeda pendapat dalam penerapan pasal dalam penertiban kasus perjudian.

Selanjutnya Nopiri (2017) tentang pemberantasan penyakit masyarakat oleh satuan polisi pamong praja ditempat hiburan malam. Penelitian yang dilakukan oleh Nopiri lebih memfokuskan kepada pihak peran Satpol PP dalam penertiban hiburan malam. Dalam penelitian ini didapat hasil penelitian bahwa pemberantasan penyakit masyarakat seperti yang diatur dalam Peraturan Daerah Nomor 1 tahun 2009 tentang pelarangan dan pemberantasan penyakit masyarakat belum dilaksanakan dengan baik. Hambatan dalam pelaksanaan pemberantasan penyakit masyarakat di kabupaten rokan hulu yaitunya bocornya informasi bahwa akan diadakannya razia, lokasi yang sulit dijangkau, serta kurangnya kepedulian dan kesadaran 
hukum masyarakat. Wuryati (2012) dalam penelitiannya melihat fenomena perilaku menyimpang remaja di kecamatan Rowosari Kabupaten Kendal. Dari hasil penelitian ditemukan bahwa bentukbentuk penyimpangan perilaku yang terjadi diantaranya adalah penyimpangan primer dan penyimpangan sekunder. Dalam penanggulangan perilaku remaja tersebut dilakukan suatu tindakan preventif, represif dan kuratif.

Berdasarkan latar belakang dan beberapa penelitian yang relevan menunjukan bahwa permasalahan penyakit masyarakat yang terjadi ditengah-tengah masyarakat sudah sangat meresahkan dan diperlukan suatu penanganan yang serius untuk mencegah maupun memberantas penyakit masyarakat. Untuk itu peneliti tertarik mengkaji fenomena penyakit masyarakat dan strategi pemerintah dalam mencegah meluasnya penyakit masyarakat di Nagari Ulakan.

\section{METODE PENELITIAN}

Penelitian ini merupakan penelitian kualitatif deskriptif yang bertujuan untuk menjelaskan bentukbentuk penyakit masyarakat dan strategi pemerintah mencegah penyakit masyarakat di Nagari Ulakan. Informan penelitian ini terdiri dari wali nagari, tokoh masyarakat (agama, adat dan kepemudaan), Babinsa dan Babinkamtibmas, yang dipilih dengan teknik purposive sampling. Proses pengumpulan data dalam penelitian ini dilakukan selama 6 bulan dengan menggunakan teknik wawancara, observasi dan studi dokumentasi. Agar memudahkan pengumpulan data, digunakan instrumen berupa pedoman wawancara dan catatan lapang serta kamera. Data yang terkumpul kemudian dianalisis dengan mereduksi data, menyajikan data, memverifikasi data dan menarik kesimpulan. Dalam menguji keabsahan data, peneliti menggunakan teknik triangulasi terhadap sumber dan teknik pengumpulan data.

\section{HASIL DAN PEMBAHASAN}

\section{Fenomena Penyakit Masyarakat di Nagari Ulakan}

Istilah penyakit masyarakat biasanya mengacu kepada semua bentuk tindakan yang bertentangan dengan norma umum, agama, adat istiadat ataupun hukum formal, sehingga dianggap tidak sesuai dengan pola tingkah laku umum dalam masyarakat (Kartono, 2011). Dalam Undang-Undang Nomor 2 Tahun 2002 tentang Kepolisian Negara disebutkan bahwa perbuatanperbuatan yang termasuk penyakit sosial antar lain penyalahgunaan narkotika, pengemis dan gelandangan, pelacuran, perjudian, miras. Lebih lanjut, Perda Kabupaten Padang Pariaman No 2/2004 menjelaskan hal serupa. Perbuatan maksiat yang dianggap sebagai penyakit masyarakat di daerah tersebut antara lain segala bentuk perzinaan dan tindakan mengarah perzinaan, perjudian, minuman keras, penyalahgunaan narkotika serta obat-obatan terlarang dan segala bentuk penyiaran tayangan pornografi.

Dari uraian tersebut kita bisa mengetahui bahwa definisi penyakit masyarakat ialah segala perbuatan yang bertentangan dengan normanorma dalam masyarakat yang bisa 
berbentuk perjudian, pelacuran / perzinaan, minuman keras dan lainlain. Lebih lanjut data mengenai fenomena penyakit masyarakat yang terjadi di Nagari Ulakan dapat dilihat pada tabel berikut:

Tabel 2

Data Penyakit Masyarakat Nagari Ulakan Tahun 2018

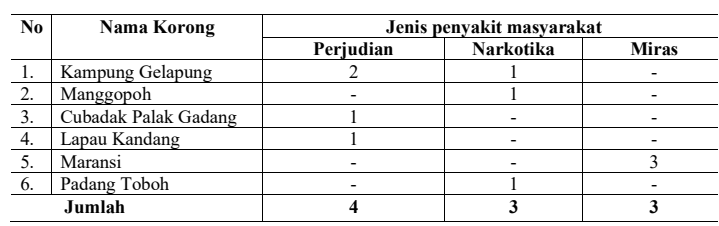

Sumber: Polsek Nan Sabaris, 2018

Dari tabel tersebut, ada 10 kasus penyakit masyarakat yang terjadi dalam kurun waktu setahun, yang terdiri dari 4 kasus perjudian, 3 kasus narkotika dan 3 kasus miras. Seluruh kasus tersebut tersebar di 6 korong yang ada di Nagari Ulakan. Antara lain Korong kampung Gelapung, Manggopoh, Cubadak Palak Gadang, Lapau Kandang, Maransi dan Padang Toboh. Bentuk kasus perjudian yang terjadi antara lain permainan song, koa, domino, remi, togel hingga judi online.

$$
\text { Dalam kasus penyakit }
$$
masyarakat yang terjadi di Nagari Ulakan, hampir seluruhnya melibatkan anak-anak muda, terkecuali kasus miras yang banyak dilakukan oleh para perantau dan pendatang. Fenomena penyakit masyarakat yang ada di Nagari Ulakan disebabkan oleh faktor lingkungan dan faktor ekonomi. Faktor lingkungan khususnya pertemanan menjadi penyebab maraknya kasus narkotika dan miras di Nagari Ulakan. Adapun faktor ekonomi masyarakat yang menginginkan mendapatkan uang dengan cara yang mudah menyebabkan banyaknya kasus perjudian di Nagari Ulakan

\section{Strategi Pemerintah Nagari Ulakan dalam Mencegah Penyakit Masyarakat}

Perda Kab. Padang Pariaman No 2/2004 memuat ketentuan bahwa dalam pencegahan dan pemberantasan perbuatan maksiat yang menjadi penyakit masyarakat, dibutuhkan peran serta dari masyarakat. Adapun penanggulangan terhadap kasus penyakit masyarakat dapat dilakukan dengan cara preventif (Setiadi, 2010). Hasil penelitian menunjukan bahwa strategi pencegahan (preventif) penyakit masyarakat yang dilakukan oleh masyarakat Nagari Ulakan, antara lain melalui sosialisasi hukum, penyuluhan bahaya narkoba, pendidikan agama, serta pengadaan kegiatan olahraga dan karang taruna.

Langkah pertama yang dilakukan oleh masyarakat Ulakan adalah dengan memberikan sosialisasi hukum Perda Kab. Padang Pariaman No 2/2004 melalui kerjasama dengan Babinsa/Babinkamtibmas, yaitu dengan kunjungan ke sekolah-sekolah maupun ke rumah-rumah warga (door to door). Selanjutnya, masyarakat juga melalukan pencegahan dengan melakukan pendekatan keagamaan seperti wirid-wirid dan pengajian yang mengajarkan tentang perbuatanperbuatan yang diperintahkan dan dilarang oleh ajaran agama. Selain itu, strategi pencegahan oleh masyarakat juga dilakukan dengan mengaktifkan kegiatan-kegiatan keolahragaan dan kepemudaan sebagai sarana penyaluran kreativitas dan mengantisipasi pergaulan buruk yang 
berpotensi menyebabkan penyakit masyarakat.

Lebih lanjut data mengenai penyakit masyarakat yang terjadi di Nagari Ulakan setelah adanya strategi pencegahan dapat dilihat pada tabel berikut:

Tabel 3

Data Penyakit Masyarakat Nagari Ulakan dalam Kurun Waktu Februari-Oktober 2019

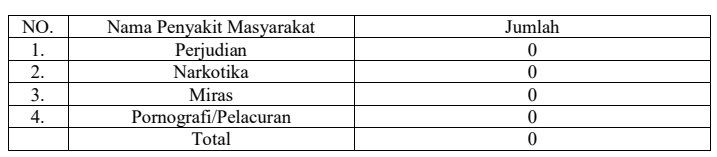

Sumber: Data Kantor Wali Nagari Ulakan

Dari tabel diatas dapat dilihat bahwa strategi pencegahan yang dilakukan oleh pemerintah Nagari Ulakan berjalan dengan baik sehingga tidak ditemukan penyakit masyarakat di Nagari Ulakan dalam kurun waktu Februari 2019 sampai Oktober 2019.

\section{SIMPULAN}

Nagari Ulakan yang dikenal begitu kental dengan nuansa keagamaan dan adat istiadat ternyata memiliki permasalahan berupa maraknya penyakit masyarakat yaitu dalam bentuk perjudian, penggunaan narkotika dan miras. Berbagai strategi untuk mengatasi pesoalan penyakit sosial tersebut telah dilakukan oleh pemerintah Nagari Ulakan. Strategi yang dilakukan pemerintah Nagari Ulakan dilakukan secara preventif. Diantaranya melakukan pendekatan secara keagamaan, melakukan sosialisasi dan penyuluhan hukum, melakukan kegiatan positif seperti kegiatan olahraga dan kegiatan karang taruna. Strategi-strategi tersebut berjalan secara efektif hal ini dapat dilihat dari data penyakit masyarakat dalam kurun waktu Februari- Oktober menunjukan hasil yang optimal dimana tidak ditemukannya penyakit masyarakat di Nagari Ulakan.

\section{DAFTAR PUSTAKA}

Hamonangan Simanjuntak. 2013, Upaya Polri dalam Menanggulangi Tindak Pidana Toto Gelap (Togel) di Kalangan Masyarakat Langkat (Studi Kasus Kepolisian Polres Langkat), Universitas Sumatera Utara

Jhon Afrizal dan Adynata. 2014, Penyakit Masyarakat di Kecamatan Bangkinang Kabupaten Kampar, Jurnal kewirausahaan. Vol 13, No 2

Juli Ardila dkk. 2016, Upaya Penanggulangan Prostitusi (Studi di Polresta Bandar Lampung)

Kartini Kartono. 2011. Patologi Sosial. Jakarta: Raja Grafindo Persada.

Peraturan Daerah Kabupaten Padang Pariaman Nomor 2 Tahun 2004 Tentang Pencegahan, Penindakan dan Pemberantasan Penyakit Masyarakat

Rival Nopiri. 2017, Pemberantasan Penyakit Masyarakat Oleh Satuan Polisi Pamong Praja Di Tempat Hiburan Malam Di Wilayah Hukum Kabupaten Rokan Hulu, JOM Fakultas Hukum Volume IV No 1

Undang-Undang Nomor 2 Tahun 2002 tentang Kepolisian Negara

Wuryati. 2012, Fenomena Perilaku Menyimpang Remaja Di Kecamatan Rowosari Kabupaten Kendal, Journal Of Educational Social Studies 1 (2) ISSN 2252 - 6390 